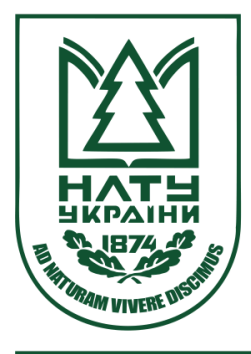

Науковий вісник НЛТУ України Scientific Bulletin of UNFU

https://nv.nltu.edu.ua

https://doi.org/10.36930/40310210

$@ \bowtie$ Correspondence author

Article received 13.04.2021 p.

Article accepted 29.04.2021 p.

O. Yu. Klepanchuk

UDC 336.76(477)

Львівський національний університет ім. Івана Франка, м. Львів, Украӥна

\title{
ІНСТИТУЦІЙНІ РЕФОРМИ ФІНАНСОВОГО РИНКУ УКРАЇНИ
}

Проаналізовано можливості конкурентного зростання внутрішнього фінансового ринку, зокрема його властивості формувати фінансову систему держави, зменшувати ризикованість інвестицій, створювати прозорий інформаційний супровід. Відзначено, що завдання фінансового ринку полягають у мобілізації та перерозподілі фінансових ресурсів 3 подальшим їх перетворенням у фінансові активи. Виявлено системні проблеми фінансового ринку, зокрема значну частку проблемних кредитів у банківській системі, недостатність власного та регулятивного капіталу банків, відсутність первинних публічних розміщень акцій українських компаній на місцевих і закордонних біржах, недосконалість українського фондового ринку. Визначено, що необхідність інституційного регулювання зумовлюється забезпеченням загальнонаціональних пріоритетів соціально-економічного розвитку та взаємовпливом інтересів учасників ринку. Окреслено стратегічні пріоритети реформування ринку, а саме розбудову конкурентоспроможного ринкового середовища відповідно до стандартів Свропейського Союзу. Виявлено стратегічні цілі реформування: стабільність фінансового сектору, інституційна спроможність регуляторів, захист прав споживачів та інвесторів. Виявлено позитивні наслідки реформування для споживачів ринку: зростання коштів бізнесу, приріст вкладів фізичних осіб, страхових платежів, операцій чинникингу, договорів лізингу, споживчого кредитування внаслідок пом'якшення монетарної політики і зниження облікової ставки. Причиною вразливості фінансового ринку визначено функціональні прогалини податкової системи України, якими зумовлюється недовиконання планових надходжень до бюджету, використання схем мінімізації податкових зобов'язань та ухилення від податків. Виявлено, що інноваційні підходи до державного нагляду банківських установ дали змогу посилити вимоги до Фонду гарантування вкладів фізичних осіб, запровадити систему оцінювання банків за європейською методологією і ризик-орієнтований підхід до банківського нагляду. Реформування потребують процедури використання електронних платіжних засобів, розвиток інфраструктури ринку, запровадження інноваційних технологій, поширення віртуальних каналів обслуговування, персоніфікація фінансових послуг, розвиток відкритого банкінгу, співробітництво з FinTech-компаніями, розвиток фінансової грамотності.

Ключові слова: регуляторне середовище; фінансові активи; інфраструктура; діджиталізація; фінансова грамотність; проактивний підхід.

\section{Вступ}

Ефективна організація внутрішнього фінансового ринку є одним 3 найважливіших чинників забезпечення стабільного економічного зростання національної економічної системи України. Особлива роль фінансового ринку зумовлюється його системотвірною позицією в організації ринкових потоків ресурсів, продукції, товарів і послуг в напрямку до споживачів та переміщення грошових потоків у зворотному напрямку, обслуговуючи кругообіг сукупного капіталу внутрішнього ринку на всіх стадіях суспільного відтворення, у виробництві, розподілі, обміні і споживанні. Отож, актуалізуються питання аналізу позитивного впливу інституційного регулювання і виявлення шляхів подальшого удосконалення функціонування внутрішнього фінансового ринку України.

Об'єкт дослідження - якісні зміни внутрішнього фінансового ринку.

Предмет дослідження - інституційні інструменти впливу на його функціонування, що дасть змогу окреслити подальші шляхи реформування внутрішнього фі- нансового ринку України.

Мета роботи - виявити сильні позиції і недоліки інституційного регулювання для окреслення подальших шляхів реформування внутрішнього фінансового ринку України, які можна використати як у теоретичних, так i практичних дослідженнях.

Для досягнення зазначеної мети визначено такі основні завдання дослідження: аналіз можливостей зростання конкурентоспроможності ринку; виявлення позитивних і негативних результатів інституційного впливу на його функціонування; окреслення напрямів, які потребують реформування.

Наукова новизна отриманих результатів дослідження - вперше проведено систематизацію чинників інституційного впливу, що дало змогу окреслити подальші шляхи реформування внутрішнього фінансового ринку України.

Практична значущість результатів дослідження виділення основних цілей стратегічних пріоритетів реформування внутрішнього фінансового ринку, які можна використати як у теоретичних, так і практичних дослідженнях.

Інформація про авторів:

Клепанчук Ольга Юріївна, канд. екон. наук, доцент, кафедра державних та місцевих фінансів. Email: o.klepanchuk@gmail.com; https://orcid.org/0000-0002-3099-6449

Цитування за ДСТУ: Клепанчук О. Ю. Інституційні реформи фінансового ринку України. Науковий вісник НЛТУ України. 2021, т. 31, № 2. С. 63-67.

Citation APA: Klepanchuk, O. Yu. (2021). Institutional reforms of Ukraine's financial market. Scientific Bulletin of UNFU, 31(2), 63-67. https://doi.org/10.36930/40310210 
Аналіз останніх досліджень та публікацій. Абсолютна більшість сучасних науковців поділяє думку про необхідність інституційного регулювання фінансового ринку для забезпечення врівноваженого попиту і пропозиції. Так, О. Ярошевська доводить існування впливу ефективності розвитку фінансового ринку на макроекономічну поведінку, зауважуючи, що основним напрямом державного регулювання має бути забезпечення розвитку в напрямі зменшення інформаційної асиметрії [14]. С. Онишко і Д. Савенко визначають інституційне забезпечення фінансового ринку як сукупність взаємопов'язаних інститутів, які забезпечують мінімізацію трансакційних витрат і ризиків опортуністичної поведінки [7]. Ю. Ставська, оцінюючи розвиток фінансового ринку в світлі глобалізаційних процесів, наполягає на необхідності пошуку шляхів стандартизації та уніфікації макроекономічної політики, універсалізації вимог податкової та антимонопольної політики країни [10]. Різні аспекти інституційного регулювання фінансового ринку досліджують і в наукових працях зарубіжних авторів. Зокрема, M. Tobal та L. Menna запропонували дискусію щодо використання монетарної політики для цілей фінансової стабільності. Автори довели взаємозв'язок між грошово-кредитною політикою та фінансовою стабільністю, який, однак, залежить від конкретних економічних характеристик і ризиків кожної економічної системи [11]. Автори розглядають фінансові кризи як ендогенні події, спричинені нагромадженням фінансових дисбалансів [1] або надмірним зростанням кредитів [2]. Отож, доцільно проаналізувати тенденції інституційного регулювання для визначення їх впливу на розвиток внутрішнього фінансового ринку України.

\section{Результати дослідження та їх обговорення}

Перерозподіл фінансових ресурсів на внутрішньому фінансовому ринку здійснюють на засадах співвідношення попиту та пропозиції, які напряму залежать від рівня конкуренції. Отож, основним завданням фінансового ринку є мобілізація і перерозподіл фінансових ресурсів суб'єктів господарювання, населення та державних грошових фондів та перетворення їх у конкретні фінансові активи. Сучасне розуміння сутності фінансових активів містить: 1) грошові кошти та їх еквіваленти; 2) контракт, що надає право отримати грошові кошти або інший фінансовий актив від іншого підприємства; 3) контракт, що надає право обмінятися фінансовими інструментами 3 іншим підприємством на потенційно вигідних умовах; 4) інструмент власного капіталу іншого підприємства [6].

Серед системних проблем фінансового ринку варто зазначити значну частку проблемних кредитів у банківській системі (48,4 \% - на початок 2020 р., 41 \% - на початок 2021 р.). Покращенню ситуації сприяли розроблені Національним банком вимоги до організації управління проблемними активами, зокрема визначення критеріїв для їх списання. Недостатність власного та регулятивного капіталу банків спричинили масовий вихід з українського ринку європейських операторів фінансового ринку. Також до проблем ринку потрібно віднести відсутність первинних публічних розміщень акцій українських компаній на місцевих і закордонних біржах, недосконалість українського фондового ринку. Водночас, у 2020 р. обсяг біржових контрактів з цінними паперами становив 282,56 млрд грн, що на 0,7 \% пе- ревищує відповідні показники 2019 року. Найбільші обсяги торгів зафіксовано з ОВДП, а саме 276,98 млрд грн (98\% від загального обсягу біржових контрактів 2020 р.). Торгівля цінними паперами зосереджувалась здебільшого на фондових біржах "Перспектива" та "ПФТС" (99,58 \% від вартості біржових контрактів) [4].

Розглядаючи питання ефективності інституційних реформ внутрішнього фінансового ринку, варто зазначити, що як складова державної фінансової системи він поєднує і організовує відповідно до ринкових правил сукупність різноманітних видів фінансових ресурсів, сконцентрованих у розпорядженні держави, суб'єктів бізнесу, незалежних фінансових інститутів і домогосподарств. Саме фінансовий ринок формує фінансову систему, забезпечуючи виконання нею функцій, притаманних ринковій економіці: перерозподіл тимчасово вільних фінансових ресурсів, забезпечення необхідного рівня ліквідності, зменшення ризикованості інвестицій, прозорість і відкритість (але одночасно - i високий рівень безпеки) інформаційного супроводу ринкової діяльності.

Ефективне функціонування фінансового ринку, його здатність мобілізовувати і перерозподіляти інвестиційні ресурси потребує чіткого визначення інституційних засад регулювання відносин між його учасниками. Необхідність регулювання зумовлюється забезпеченням, 3 одного боку, загальнонаціональних пріоритетів соціально-економічного розвитку, а $з$ іншого - взаємовпливом інтересів учасників ринку. Основними регуляторами внутрішнього фінансового ринку є Національний банк України, який здійснює регулювання грошового ринку (включаючи валютний, депозитний і кредитний ринки), Національна комісія 3 цінних паперів та фондового ринку, на яку покладено функції регулювання ринку капіталу, нагляд за його учасниками, а також захист інтересів інвесторів виконує функції регулювання ринку капіталу. Окрім цього, інституційні важелі впливу на розвиток фінансового ринку мають Міністерство фінансів України (формування і реалізація державної фінансової та бюджетної політик, регулювання митної та податкової сфери, фінансове забезпечення виконання державних функцій), Національний депозитарій (забезпечення функціонування системи депозитарного обліку цінних паперів), Рахункова палата (орган фінансово-бюджетного контролю Верховної Ради України), Фонд державного майна (реалізація державної політики у сфері використання та відчуження державного майна). Функціонування фінансового ринку контролюється Антимонопольним комітетом України (державний захист конкуренціï) та Державною службою фінансового моніторингу України (протидія відмиванню доходів, одержаних злочинним шляхом).

Основні стратегічні пріоритети реформування фінансового ринку [5], спрямовані на розбудову повноцінного ринкового конкурентоспроможного середовища згідно зі стандартами Свропейського Союзу. Реформа відбувається за трьома напрямами: забезпечення стабільності фінансового сектору, розбудова інституційної спроможності регуляторів, захист прав споживачів та інвесторів фінансового сектору. Реформа монетарної політики дала змогу певною мірою стабілізувати банківську систему. Зокрема, впровадження принципу незалежності НБУ створило умови для забезпечення стабільності гривні. Переорієнтація монетарної політики 
на досягнення інфляційних цілей і перехід до режиму плавучого обмінного курсу сприяли макроекономічній стабілізації. Фіскальна політика полягала в істотному зниженні дефіциту державного сектору, скороченні рівня державного боргу (рис. 1) та впровадженні середньотермінового бюджетного планування.

Запровадження ліберального валютного регулювання у 2016 р. [5] спрямовано на дерегуляцію інвестицій і дало змогу нерезидентам України відкривати рахунки в українських банках для функціонування інвестиційних фондів і компаній з управління активами.

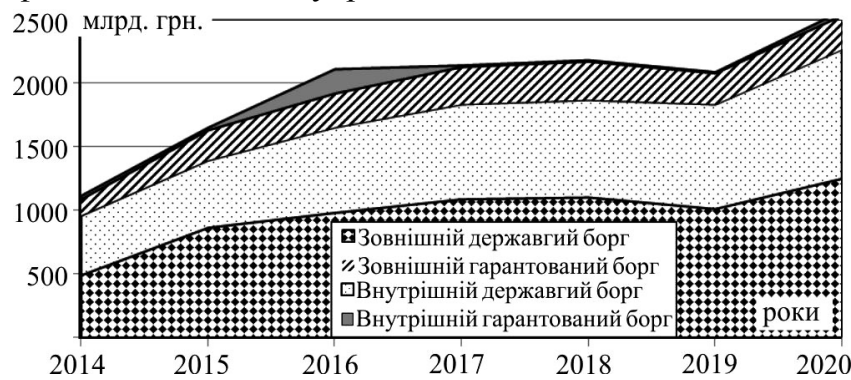

Рис. 1. Динаміка зміни державного боргу України у 2014-

2020 pp. (побудовано за [4])

Окрім цього, до інфраструктури українського фондового ринку було підключено депозитарій цінних паперів Clearstream. Однак повного переходу до режиму вільного руху капіталу на внутрішньому фінансовому ринку неможливо досягти за наявних макроекономічних умов. Окрім цього, ефективне функціонування ринку потребує включення України до системи автоматичного обміну інформацією щодо фінансових рахунків.

Зміни сприяли зростанню зобов'язань банків (до кінця 2019 р. їх рівень становив 1,29 трлн грн), що передусім треба пов'язувати із приростом припливу коштів клієнтів у банківський сектор, сумарна частка яких сягнула історичного максимуму - 83,3 \%. Водночас, через погашення кредитів рефінансування державними банками частка коштів Національного банку стабільно зменшувався валовий зовнішній борг банків і небанківських фінансових установ, сягнувши 0,6 \% на кінець 2019 р. (рис. 2). Позитивним наслідком реформування стало зростання на 19,5\% гривневих коштів бізнесу, переважно за рахунок приросту в державних банках (28,3\%), зростання валютних коштів на 48,4\% [6]. У 2017-2019 рр. спостерігався стабільний приріст вкладів гривневих коштів фізичних осіб, чому сприяли посилення позицій національної валюти та низькі ставки за валютними депозитами.

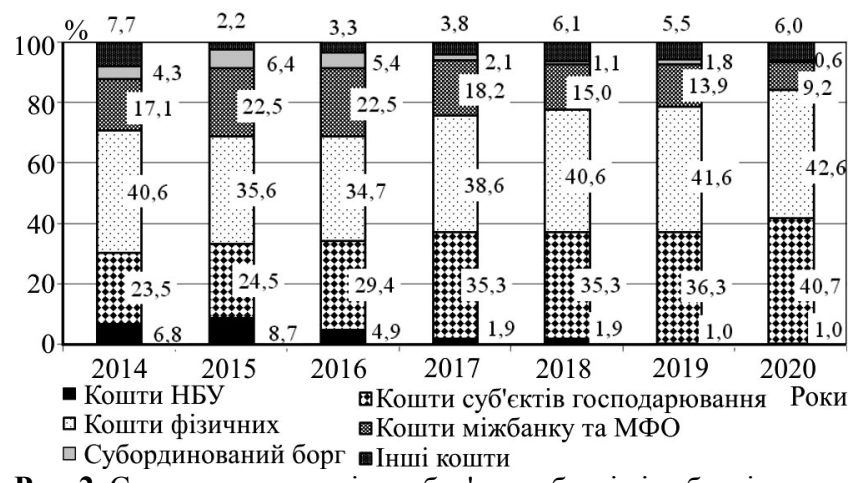

Рис. 2. Структурна динаміка зобов'язань банків і небанківських фінансових установ у 2014-2019 рр. (побудовано за [6])

Інституційне реформування також вплинуло на зміни кредитної активності банків і небанківських фінан- сових установ, що проявилось зростанням споживчого кредитування (гривневих кредитів) на понад $25 \%$ за період 2014-2019 років. Завдяки сповільненню інфляції у 2019 р. було пом'якшено монетарну політику та знижено облікову ставку від 18 до 13,5 \%, що сприяло певному здешевленню кредитних ресурсів для корпоративних клієнтів, однак їх вартість для фізичних осіб залишалася стабільно високою.

Обговорення результатів дослідження. Ефективний розвиток внутрішнього фінансового ринку потребує дотримання певних принципів, зокрема забезпечення прозорості і вільного доступу до інформаційних потоків, доступності ринкових інструментів для всіх його учасників, захисту прав інвесторів, відповідності міжнародним стандартам. Метою інституційного реформування внутрішнього фінансового ринку є забезпечення стійкості фінансової системи України. Недосконалість бюджетної збалансованості може чинити істотний дестабілізаційний вплив на функціонування фінансової системи, спрямовуючи наявні ресурси на компенсацію дисбалансів. Варто зазначити, що в цьому випадку ми не розглядаємо питання проблем вітчизняної економічної системи щодо генерації фінансових ресурсів, а концентруємо увагу на інституційній спроможності фінансового ринку до їх акумулювання, адже акумульовані фінансові ресурси можуть виступати в ролі інструментів стабілізації економічних процесів.

Основною причиною вразливості фінансового ринку у забезпеченні фіскальної стійкості дохідної частини бюджету є функціональні прогалини податкової системи України. Широке розповсюдження схем мінімізації податкового навантаження містить порушення митних правил, розкрадання податку на додану вартість, переміщення прибутків до податкових офшорів, тіньові схеми оренди землі, тіньові схеми нарахування заробітної плати, приховування реальних обсягів продажу для викривлення бази оподаткування, зловживання податковими пільгами, неофіційне підприємництво.

Зокрема, недовиконання планових надходжень до бюджету відбувається через критичне поширення схеми мінімізації податкових зобов'язань та ухилення від податків. Значна поширеність цієї проблеми спонукає до більш докладного розгляду їі особливостей і можливостей інституційного впливу для ii вирішення. Так, злочинна схема контрабанди та "сірого" імпорту містить недостовірне митне декларування (фальсифікації щодо ваги, вартості, номенклатури товарів у супровідних документах), ввезення вантажів в обхід митних пунктів пропуску, дроблення великих партій товарів тощо. За експертною оцінкою фахівців Інституту соціально-економічної трансформації, щорічні збитки бюджету від контрабанди і схем "сірого імпорту" становлять 6393 млрд грн [3]. Зазначимо, що такі схеми не тільки негативно впливають на рівень митних платежів, акцизу та ПДВ, але й мають розглядатись як чинники виникнення умов недобросовісної конкуренції щодо товарів національних виробників на внутрішньому ринку.

На ефективності функціонування внутрішнього фінансового ринку негативно позначаються проблеми, пов'язані із застосуванням трансфертного ціноутворення, яке часто використовують експортери української продукції для уникнення від сплати податків. Так, за ціною, нижчою за ринкову, у 2017-2018 рр. здійснювали 
експорт залізної руди (20 \% недооцінення, що призвело до щорічного недоотримання платежів до бюджету в сумі близько 750 млн євро), пшениці та кукурудзи (10,4 та 7,6 \% недооцінення відповідно, що призвело до недоотримання 270 млн дол. США) [9]. Загалом щорічні втрати фінансового ринку України від незаконних транскордонних потоків (торгових, банківських та інвестиційних) сягають $0,54 \%$ ВВП або близько 21,7 млрд грн. Для протидії описаним зловживанням на фінансовому ринку і витіснення "офшорних конструкцій" із внутрішнього ринку України у 2017 р. Україна приєдналася до Плану з розробки заходів протидії розмиванню податкової бази та виведенню прибутку (BEPS) [13]. Зазначимо, що інституційний вплив на функціонування фінансового ринку за планом BEPS містить перспективні ініціативи щодо захисту внутрішнього фінансового ринку та зростання ефективності його функціонування: правила оподаткування цифрового сектору економіки, боротьба з гібридними податковими схемами, ефективні правила контролю, запобігання зловживанням схемами уникнення подвійного оподаткування, правила трансфертного ціноутворення, аналізу і моніторингу інформації про ризики, уніфікація документації тощо. Участь в BEPS стала поштовхом для лібералізації внутрішнього фінансового ринку, дала змогу впровадити інструментарій боротьби з офшоризацією бізнесу. Отож, сьогодні актуалізуються питання реалізації нормативного інструментарію для оздоровлення фінансового ринку, а також налагодження діяльності органів контролю щодо автоматизації обміну фінансовою інформацією.

Завдяки реформуванню було запроваджено нові підходи до державного нагляду банківських установ, значно посилились вимоги до інституційної спроможності Фонду гарантування вкладів фізичних осіб, запроваджено нову систему оцінювання банків відповідно до європейської методології "Supervisory review and evaluation process" та ризик-орієнтований підхід до виїзного та безвиїзного банківського нагляду. Рейтингові оцінки CAMELS доповнені новим компонентом "Операційний ризик" й актуалізованими критеріями оцінок. Нормативно визначені принципи, основні цілі та вимоги до побудови системи управління ризиками, управління проблемними активами та системи внутрішнього контролю у банках.

Значна частина адміністративних новацій на фінансовому ринку стала можлива завдяки активній діджиталізації. Зокрема, запроваджено єдину операційно-інформаційну систему неплатоспроможних банків, автоматизовану систему виплат вкладникам, систему стрестестування та раннього попередження, повноцінну систему розрахунку регулярних зборів у вигляді диференційованих зборів з урахуванням ризиків банків. Продаж активів неплатоспроможних банків здійснюється на прозорих та конкурентних умовах через електронні платформи. Відповідно до міжнародних стандартів запроваджено використання міжнародного номера банківського рахунку IBAN та інструментів ідентифікації BankID, розпочато пілотний проєкт для підтримки FinTесh-рішень.

Реформи фінансового ринку сприяли підвищенню фінансової стійкості та прозорості діяльності банківських установ. Зокрема, законодавчо оформлене підгрунтя для спрощеної капіталізації банків, запроваджено системне макропруденційне регулювання, налагоджено систему регулярного оцінювання якості активів та стрес-тестування банків, оцінювання кредитних ризиків приведено у відповідність до Базельських рекомендацій [8]. Зазначимо, що цими рекомендаціями вводять жорсткі стандарти нагляду за банківською діяльністю, зокрема підвищують вимоги до розкриття інформації 3 питань управління ризиками. Для підвищення надійності та стабільності банківської системи створено Кредитний реєстр.

Важливими напрямами інституційного реформування фінансового ринку стала зміна стандартів корпоративного управління та посилення захисту прав інвесторів. Законодавчі ініціативи щодо удосконалення правового регулювання охоплюють процедури емісії цінних паперів, розкриття інформації, а також містять інструменти захисту прав інвесторів, процедури squeeze-out та sell-out, а також механізм відкриття і використання клієнтами банку рахунків умовного зберігання. Позитивною інституційною новацією 2019 р. стало наділення регуляторів фінансового ринку повноваженнями із захисту прав споживачів фінансових послуг [12]. Це сприятиме зміцненню довіри громадян до операторів фінансового ринку, осучаснить механізми захисту їх прав.

Надзвичайно важливим чинником зміцнення довіри споживачів фінансових послуг $\epsilon$ організація державноприватних проектів підвищення фінансової грамотності. На сьогодні за рівнем фінансової грамотності Україна відстає від абсолютної більшості країн - членів OECP (13,2 бали з можливих 21, за методикою ОЕСР). Отож, у 2019 р. Національним банком України було презентовано проєкт стратегії фінансової грамотності [6], ключові 4 рішень-пріоритетів якої містять зміну фінансової культури, формування європейських, фінансово обізнаних українців, фокус на молодь, розроблення єдиної комунікаційної платформи і створення єдиного освітньо-інформаційного центру.

Проблема недостатності інвестицій є комплексною і пов'язана $з$ тіньовим обертанням значного обсягу ресурсів, макроекономічною нестабільністю та недостатньою диверсифікованістю вітчизняної економіки, що перешкоджає формуванню класу фундаментальних довготермінових інвесторів. Також недостатність інвестицій на фінансовому ринку зумовлюється обмеженістю ліквідних та інвестиційно привабливих фінансових інструментів, низькою ліквідністю та капіталізацією, недосконалістю судової системи.

Недостатньо розвиненою та ефективною залишається інфраструктура ринків капіталу. Для іiі модернізації відповідно до міжнародних стандартів за підтримки ЄБРР розроблено цільову модель депозитарної, розрахункової та клірингової інфраструктури [6], спрощено процедури іноземного інвестування шляхом запровадження правового режиму обліку права власності на цінні папери. Водночас, залишаються невирішеними проблеми ринкового розвитку біржових активів, що перешкоджає прозорому ціноутворенню на енергоносії, агропродукцію, продукцію хімічної промисловості тощо.

\section{Висновки}

Стрімкий розвиток нових технологій зумовлює зростання конкуренції у всіх секторах фінансового ринку. Активізація функціонування ринку забезпечується до- 
волі потужним інституційним регулюванням останніх років. Завдяки удосконаленню регуляторного середовища на фінансовому ринку відбулося зростання активів, страхових платежів, операцій факторингу, кредитування, договорів лізингу, що можна розглядати як передумову зростання внутрішнього ринку України. Однак реформування потребують питання використання електронних платіжних засобів, розвитку інфраструктури ринку, розвитку фінансової грамотності. Розвиток інноваційних технологій, поширення віртуальних каналів обслуговування, персоніфікація фінансових послуг, розвиток відкритого банкінгу, співробітництво 3 FinTесh-компаніями $\epsilon$ передумовами кращого задоволення потреб клієнтів, вимагаючи, водночас, від регуляторів фінансового ринку проактивного підходу до регулювання взаємовідносин його учасників. Проте залишаються невирішеними проблеми ринкового розвитку біржових активів, що перешкоджає прозорому ціноутворенню.

\section{References}

1. Bruno, V., Shim, I., \& Shin, H. S. (2017). Comparative assessment of macroprudential policies. Journal of Financial Stability, 28, 183-202. https://doi.org/10.1016/j.jfs.2016.04.001

2. Cúrdia, V., \& Woodford, M. (2016). Credit frictions and optimal monetary policy. Journal of Monetary Economics, 84, 30-65. https://doi.org/10.1016/j.jmoneco.2016.10.003

3. Dubrovskyi, V., Cherkashyn, V., \& Hetman, O. (2020). Comparative analysis of the fiscal effect of tax evasion / avoidance instruments in Ukraine: new challenges. Kyiv: Institute of SocioEconomic Transformation, $360 \mathrm{p}$.

4. Ministry of Finance of Ukraine (2021). Official site. Retrieved from; https://minfin.com.ua
5. National Bank of Ukraine (2015). On approval of the Comprehensive Program for the Development of the Financial Sector of Ukraine until 2020: Resolution № 391 of June 18, 2015. Retrieved from; https://zakon.rada.gov.ua/laws/show/v0391500-15\#Text

6. National Bank of Ukraine (2021). Official site. Retrieved from; https://bank.gov.ua/

7. Onyshko, S. V., \& Savenko, D. O. (2020). Theoretical conceptualization of institutional support of the financial market. Business Inform, 9, 512 p. https://doi.org/10.32983/2222-4459-2020-9-219-228

8. Shynkar, M. (2017). Basel Recommendations in the Context of Improving the Stability of the Banking System as Legal Measures to Prevent Bankruptcy of Banking Institutions. Entrepreneurship, economy and law, 7, 104-108.

9. State Fiscal Service of Ukraine (2021). Official portal. Retrieved from: http://sfs.gov.ua/

10. Stavska, Yu. V. (2020). The impact of globalization of the world economy on the development of the financial market. Modern Economics, 20 (2020), 261-266. https://doi.org/10.31521/modecon.V20(2020)-40

11. Tobal, M., \& Menna L. (2020). Monetary policy and financial stability in emerging market economies. Latin American Journal of Central Banking, https://doi.org/10.1016/i.latcb.2020.100017

12. Verkhovna Rada Ukrainy (2019). On amendments to some legislative acts of Ukraine on the protection of the rights of consumers of financial services: Law of Ukraine № 122-IX of 20.09.2019. Retrieved from; https://zakon.rada.gov.ua/laws/show/122-20\#Text

13. Verkhovna Rada Ukrainy (2021). On Amendments to the Tax Code of Ukraine to Improve Tax Administration, Eliminate Technical and Logical Inconsistencies in Tax Legislation: Law of Ukraine № 466-IX as amended on 01.01.2021. Retrieved from; https://zakon.rada.gov.ua/laws/show/466-IX

14. Yaroshevska, O. V. (2020). Problems of financial market development in the categories of modern economic theories. Economy and State, 8, 15-19. https://doi.org/10.32702/23066806.2020.8.15

O. Yu. Klepanchuk

Ivan Franko National University of Lviv, Lviv, Ukraine

\section{INSTITUTIONAL REFORMS OF UKRAINE'S FINANCIAL MARKET}

A crucial role of financial market is determined by its system-forming position in the organization of market flows of resources, products, goods and services to consumers and the movement of cash flows in the opposite direction, serving the total capital of domestic market at all stages of social reproduction, production, distribution, exchange and consumption, which actualizes the positive impact of institutional regulation and identifies ways to further improve its functioning. Internal financial market combines and organizes a set of different types of financial resources concentrated at the disposal of the state, business entities, independent financial institutions and households in accordance with market rules. The need for institutional regulation is due to ensuring national priorities of socio-economic development and the interaction of the interests of market participants. The main regulators of financial market are the National Bank of Ukraine and the National Commission on Securities and Stock Market. The Ministry of Finance of Ukraine, the National Depository, the Accounting Chamber, and the State Property Fund also have some institutional levers of influence. Control over the functioning of financial market is provided by the Antimonopoly Committee and the State Financial Monitoring Service. The strategic priorities of financial market reforms include building market competitive environment in line with European Union standards in three areas such as ensuring the stability of a financial sector, building the institutional capacity of regulators, and protecting the rights of consumers and investors in the financial sector. Liberalization of currency regulation has allowed the operation of international investment funds. The stock market infrastructure is connected to the securities depository Clearstream, but there is a need to include in the system of automatic exchange of information on financial accounts. At the same time, tax evasion schemes are critically widespread, which can be considered as factors in the emergence of conditions of unfair competition. To combat abuse, Ukraine has joined the Plan to Develop Measures to Combat Tax Erosion and Profit Recovery (BEPS), but the implementation of regulatory tools for financial market recovery and automation of financial information exchange remains unsolved. The problems of financial literacy development, innovative technologies, distribution of virtual service channels, personalization of financial services, open banking, and cooperation with FinTech companies are still urgent, which requires regulators to take a proactive approach to regulating the relations of market participants.

Keywords: regulatory environment; financial assets; infrastructure; digitalization; financial literacy; proactive approach. 